\section{Scientific journal}

PHYSICAL AND MATHEMATICAL EDUCATION

Has been issued since 2013.

Науковий журнал

ФІЗИКО-МАТЕМАТИЧНА ОСВІТА

Видається 32013.
ISSN 2413-158X (online)

ISSN 2413-1571 (print)

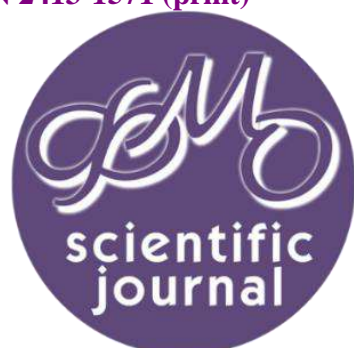

Биндас О.М. Особливості висвітлення та інтерпретації контраверсійних подій в Україні європейськими ЗМІ. Фізикоматематична освіта. 2020. Випуск 4(26). С. 7-12.

Byndas 0 . Peculiarities of highliting and interpreting news about controversy events in Ukraine by european media. Physical and Mathematical Education. 2020. Issue 4(26). P. 7-12.

DOI 10.31110/2413-1571-2020-026-4-001

UDC 308(430)"17

O. Byndas

State Institution "Luhansk Taras Shevchenko National University", Ukraine olenataran@ukr.net

ORCID: 0000-0003-4213-5563

\title{
PECULIARITIES OF HIGHLITING AND INTERPRETING NEWS ABOUT CONTROVERSY EVENTS IN UKRAINE BY EUROPEAN MEDIA
}

\section{ABSTRACT}

Formulation of problem. The article deals with the problem of multidimensional disclosure of the specifics of highlighting and interpreting the information about the controversy events in Ukraine during the information war on the air of the European television channel of international news - Euronews.

Materials and methods. The information sources are the documents of the funds of the National Television Company of Ukraine (NTCU) and the Inter Media Group, which allowed to trace the stages of formation and development of cooperation between Euronews board and Ukrainian partners during 2014-2020, We also referred to HAL, a multi-disciplinary open access archive for the deposit and dissemination of scientific research documents, whether they are published or not. The documents may come from teaching and research institutions in France or abroad, or from public or private research centers (Baisnée \& Marchetti, 2014).

Results. The author emphasizes that despite the existence of the only editorial policy, the journalists of Euronews editorial office independently write the text to the selected news, so its absolute identity is almost impossible. In fact, the analysis of the produced content confirmed the constancy and saturation of the linguistic components of the information genre and showed, on the one hand, bias, prejudgment and manipulative nature of the mass communication activities of the Russian Euronews service, and, on the other hand, compliance with the standards of media literacy in Ukrainian, English and German editors. At a time when the information war is accompanied by Russia's military action against Ukraine, the problem of compliance with the rules of media literacy in media publications is especially relevant. It is important to disseminate truthful information about events in Ukraine both within our country and abroad. Thus, this study is relevant, and the choice of the object and the source base of the study is quite logical: the "Euronews" TV channel broadcasts in thirteen languages and covers a wide audience in different countries.

Conclusions. Having analyzed the program content of the European media, we state that the national editors of information programs actively covered events related to the controversy events in Ukraine. At the same time, on its way to the air, the media product passes through a whole selection of fountains, interrogations, journalistic work, influences and saturation of media texts by lexical and stylistic forms inherited in one or another language. But the editorial board does not evaluate and support any of the parties covered the conflicts, giving each of them the opportunity to express their own point of view.

KEY WORDS: editor, channel, to broadcast the news, territorial conflict, the East of Ukraine, European media.

\section{INTRODUCTION}

Modern technologies for creating, highlighting and promoting content in the media are fast-paced. At the same time, high-quality publications, in addition to multimedia and hypertextuality, give special attention to text content, which should meet not only modern standards of journalism, but also take into account linguistic, cultural and communicative features of recipients. From the fact the material is professionally, meaningfully, and normatively provided, the further proximity of such a resource in the media depends. Traditional for mass media in general and for television in particular, text forms remain relevant as they are basic for creating a media product. Thus, speaking of the actual media texts, including the titles, we note that this genre is focused on news messages, statements of facts, without analysis and evaluation, with a neutral vocabulary.

Nowadays the international community follows the news about Ukraine as "six years since the start of its "Euromaidan" revolution, Ukraine is fighting for its survival as an independent and viable state (Thornton, 2015).

At a time when the information war is accompanied by Russia's military action against Ukraine, the problem of compliance with the rules of media literacy in media publications is especially relevant. It is important to disseminate truthful information 
about events in Ukraine both within our country and abroad. Thus, this study is relevant, and the choice of the object and the source base of the study is quite logical: the "Euronews" TV channel broadcasts in thirteen languages and covers a wide audience in different countries.

The aim of the proposed article is a multifaceted disclosure of the peculiarities of presenting information about the controversy events in Ukraine during the information war on the air of the European international news channel - Euronews.

The information sources are the documents of the funds of the National Television Company of Ukraine (NTCU) and the Inter Media Group, which allowed to trace the stages of formation and development of cooperation between Euronews board and Ukrainian partners during 2014-2020, We also referred to HAL, a multi-disciplinary open access archive for the deposit and dissemination of scientific research documents, whether they are published or not. The documents may come from teaching and research institutions in France or abroad, or from public or private research centers (Baisnée \& Marchetti, 2014).

\section{THEORETICAL FRAMEWORK}

Euronews is a European, multilingual news television channel (a commercial one), headquartered in Lyon-Ecully, France. Created in 1993, it claims to be covering world news from a Pan-European perspective (Euronews, 17 July 2020). Euronews broadcasts 24/7 thirteen services - Arabic, English, French, German, Greek, Hungarian, Italian, Persian, Portuguese, Russian, Spanish, Turkish and Ukrainian.

Euronews broadcasts consist of direct inclusions and stories about socio-political, economic and cultural events in Europe, the activities of European authorities, the development of science, and the social problems of European populations. Euronews's round-the-clock broadcasting is the same all over the world, but with identical video, the text of each language version is original. This is due to the fact that journalists write "the voice" to the mounted video at the same time and in parallel, without checking any single model and guided by the same editorial policy. In addition to greater efficiency, such an organization of work provides an individual content that is adequate to the needs of a diverse audience (Euronews, NTKU, 5 July 2020). Despite the existence of the only editorial policy, the journalists of each language editorial office independently write the text to the selected news, so its absolute identity is almost impossible. Especially when it comes to coverage of pressing political and social issues.

The largest stakes in Euronews belong to:

- French State Television Corporation "France Television" (25.37\%);

- Italian State Television Corporation RAI (22.84\%);

- All-Russian State Television and Broadcasting Company VGTRK (16.94\%);

- Turkish State Television Corporation TRT (15, 7\%);

- Swiss Public Television Corporation SSR (9.2\%);

- 21 public and state channels of European countries (Ash\&Gunn, 2017).

As for Euronews' own editorial policy, the main principles and the principles of its work are full non-interference with editorial policy by anyone: political forces, lobbying interests and money. It is an independent editorial policy, balanced submission of information, representation of two or more points of view, under no circumstances to be on one side or another, to show what is really happening, to enable the viewer to make his/her own conclusions. And also efficiency, honesty, adherence to principles and decency.

After all, the creation of Euronews was perceived by its initiators as a means of finding a new prop that would contribute to forging a "European identity" and a "European public space". A segment of the European political executive leadership strongly believed in the impact of the media in constructing a cultural homogeneity, thus assuming that distributing the same cultural product would contribute to the formation of the same interpretation by its viewers. This political voluntarism and its logic, which led to support for the creation of Euronews, was visible in the Commission's discourse on the questions of culture and identity (Baisnée, 2012: 6).

The research by N. Chomsky and E. Hermann "Manufacturing Consent: The Political Economy of the Mass Media" proves the existence of a "propaganda model" of the media. "This book centers in what we call a propaganda model, an analytical framework that attempts to explain the performance of the U.S. media in terms of basic institutional structures and relationships within which they operate. It is our view that, among their other functions, media serves and propagandizes for the powerful social interests that control and finance them" (Herman \& Chomsky, 1988: 412). The researchers speak about the structural factors of the model, which are "ownership and control", the dependence on the main sources of financing, especially from advertisers, mutual interest and the link between the media and those who make the news and have the power to define it and explain what it means". The "propaganda model" includes a number of other factors, described in detail in the concept of "five filters". The authors are convinced: "What journalists do, what they see as newsworthy, and what they take for granted as the premises of their work are often explained by incentives, pressures, and constraints" (Herman, 1988: 203).

Television attracts the interest of the international community and academics in the formation of such a discourse as involving the population of the territories in socio-political processes and imposing a certain world view through electronic media. Such actions are more characteristic of regional and national television, not only because of its proximity to the audience, but also because of full or partial dependence on local financial, economic and political elites. However, a detailed analysis of the functioning of supranational telecoms suggests that elements of manipulation and imposition of a certain world view are also characteristic of European broadcasters and, in particular, Euronews. In order to understand the mechanisms of such influence, one should consider the specifics of journalists' work of different language editors and analyze the content.

\section{RESULTS}

In the Euronews editorial (23 February 2014) Ukrainian, Russian, English and German services interpret the events of clashes between supporters and opponents of Euromaidan in Donetsk and Crimea in different ways. It is clear even from the headlines which accents each of the editors placed in the materials in their national language. 
The journalists of the English-language intelligence service report on "Outbreak of violence / cruelty in Ukraine: "Violence erupts in Ukraine as pro-Russian protesters clash with Kyiv supporters" (Euronews. Here we go, 2014). The title "prepares" the viewer for the fact that he finds details of cruelty in the material.

In fact, the second paragraph of the material in English reports that "Several attempts by opposition supporters to hold rallies over this weekend's historic events have been roundly shut down". There are no details of exactly where the described events happened and the exact "attempts" that were "roundly shut down", but the word "roundly" suggests a person, who does not have the habit of reading one news in Ukrainian, Russian and German, that in Ukraine there was "violence" indeed. However, the third paragraph of the article describes rather sparingly the events in Donetsk: "In the poor industrial city of Donetsk, proRussian protesters made their feelings clear over their allegiances".

Thus, let's compare the coverage of that day events in Crimea as well, as the English version did not specify the place where the "violence" occurred, it did not necessarily have to be Donetsk, perhaps it is about Crimea. However, in English it is written quite reluctantly again: "A scene has been repeated in several other cities like Kerch in Crimea, where some Ukrainians have spoken openly of their desire to see the country split along political lines." From such a dry presentation of information it is not clear why the English headline sounds so "strongly", although the material in English is losing its content in comparing with other languages.

In the materials in English, there are different language figures, such as questions of different types, repetitions created by means of different language levels, applications and structural and graphical selections (at the level of the online version of audiovisual materials).

The German edition publishes the material "Yanukovych's followers came to protest in the East of Ukraine" ("Janukowitsch-Anhänger demonstrieren im Osten der Ukraine") (Previsic, 2014).

Firstly, the German version of pro-Russian supporters was identified with supporters of Yanukovych. Secondly, only the East of Ukraine is mentioned.

In the German headline, there is nothing to suggest about cruelty or even clashes, since, as a rule, the nature of protests is peaceful. As regards the coverage of events in Donetsk, their course is described in a rather "peaceful" way: "In the city of Donetsk, which is in the East of the country, Yanukovych's supporters walked along streets with Russian flags, impeding the carrying out of a memorial service for victims of disturbances on Maidan" ("In der Stadt Donetsk im The Osten des Landes zogen Janukowitsch-Anhänger mit der Russischen Flagge der Straßen und Störten eine Gedenkfeier für die Opfer der Maidan-Unruhen"). The text formulation in German suggests that "supporters of Yanukovych" prevented the carrying out of the memorial service by those who went through the streets of the city. The headline is centered on Eastern Ukraine, but the material also mentions Crimean events - "On the Crimean Peninsula, in the city of Kerch, pro-Russian supporters of Yanukovych demanded the separation of the region and joining it to Russia, chanting "Russia, Russia". ("Auf der Halbinsel Krim in Kertsch Forderten die prorussischen Janukowitsch-Anhänger eine Abspaltung der Region zu Gunsten Russlands. Sie riefen "Russland, Russland". Though only the German speaker refers to the pro-European rhetoric that Yanukovych's "furious supporters have thrown into eggs" ("Eine pro-europäische Rednerin wurde von wütenden Janukowitsch-Anhängern mit Eiern beworfen, ihr Pult wurde umgestoßen, sie musste sich in Sicherheit bringen." Die aufgebrachten Männer riefen: "Haut ab, Faschisten!" (Previsic, 2014)

Comments in all language editions are the same because they are selected by editors, not journalists. Therefore, the direct speech ("I think that at the moment Russia is in a position of waiting. But we hope that if Russia starts something like war, as it was in Ossetia, Russia, of course, will not stand aside") is identical in all four languages (Euronews. 2014 Ordinary Session).

The English-language version of Euronews on highlighting Russia's issue of giving Russian passports, for instance, to the inhabitants of Crimea, as well as their Russian counterparts, says nothing about: "Russian MPs raise the prospect of citizenship in Crimea visit"), but writes that Russian deputies from the liberal-democratic party "delivered the message" about the possibility for the Crimeans to claim Russian citizenship. They considered this question, or only "will discuss during the visit" (Euronews. Krym, 2019) is not reported.

The grammar of the English version of the audiovisual product has the following features, such as a certain peculiarity in the use of times and conditions, the frequent use of impersonal forms, special forms of the introduction of direct speech and its transformation into indirect, as well as the widespread use of complex sentences, while the grammatical specificity of the style of the Ukrainian language is expressed less clearly, here is the use of passive constructions and generalized-personal forms of verbs. Such discrepancies constitute some difficulties in the perception of an audiovisual product.

It should be noted that English journalists provide their recipients with brief historical references: who, when, why gave Crimea to Ukraine. It is not surprisingly, why it does not need to remind its audience of the Ukrainian and Russian services of Euronews.

On 3 March 2014 the material on the extraordinary session of the Council of the European Union on Foreign Affairs and the decisions made there is broadcasted. The materials of the Ukrainian, English and German versions come with similar headings: "EU calls on Russia to "de-escalate acts of aggression" in Ukraine"), "EU calls on Russia to stop military operation in Crimea" ("EU verlangt Ende des russischen Militareinsatzes auf der Krim") (Euronews. EU, 2019).

The information contains a message that the EU has called for Russia to withdraw troops from the territory of Ukraine. The Ukrainian edition writes that "the leaders of foreign policy departments unanimously condemned Russian aggression" (the phrase "Russian aggression" is also found in the material in English). As with other language versions, Ukrainian leads the direct speech of the EU High Representative for security and foreign affairs, K. Ashton: "We need to see the return of Russian troops to the barracks and places of deployment, as defined by the agreement with Ukraine. We are seriously concerned about reports of military flights, troop movements and armored vehicles in various locations. I think it's clear that we want to see the return of troops to the positions that they held before the conflict began" (Myers\&Smale, 2014).

Referring to The Wall Street Journal, journalists report on the possibility of the EU to "freeze negotiations on a visa-free regime with Russia in case of further military operations against Ukraine" ("military operation" is also found in German). An 
appeal to both sides was made by the Foreign Minister of Germany Frank Steinmeier: "25 years after the end of the Cold War, Europe once again faced a split up. I ask myself whether the time has come to send a clear signal to Russia that its military actions are completely unacceptable and to urge the Ukrainian government to respect the rights of minorities in the East of Ukraine" (Steinmeier, 2014).

In the materials of 12 April 2014, the capture of the Main Directorate of Police in Donetsk is reported. Ukrainian journalists in the article entitled "Who controls Donetsk after the detention of the heads of the Ministry of Internal Affairs and the SSU?" write that the department of the Ministry of Internal Affairs stormed "unknown people in camouflage."

The title of another material in English most objectively transmits the content of the described events: "Pro-Russian separatists seize Donetsk police HQ" (Euronews. Khto, 2014). How exactly they "took control" was not reported, but noted that "they have met with 1itt1e or no resistance as the city's roles chief has resigned".

The display texts are full of special terms related to political and public life, contain names of political parties, state institutions, public organizations and terms related to their activities (Security Council, term of office, cold war, etc.).

The headline of the article in German "Oppositionists / Protesters in the East of Ukraine demand the Dismissal of Head of Donetsk Police" ("Ostukrainische Regierungsgegner zwingen Polizeichef von Donezk zum Rücktritt") focuses on events that other language editions cover as a fulfilled fact: Head of Donetsk police resigned. The German edition publishes another interesting detail: "According to witnesses, about 200 people stormed the building" ("etwa 200 Personen das Gebäude") (Euronews. Ostukrainische, 2014). They intended to seize the chemical plant mentioned in the Ukrainian version of the material. Also, with no reference to sources, journalists report about "about 1000 people" who came to a rally against Kiev authorities.

\section{DISCUSSIONS}

As we can see, jargon and other lexical elements of colloquial style are used in the audiovisual headings. Even if the television version describes the situation in a more restrained style, the title may be more conversational, which uses the verb "sack", which is household-colloquial. The widespread use of functional styles in the media language is conditioned by specific conditions of communication in various spheres of human activity and communicative processes. Therefore, the main characteristic features of the media language are included (Vladymyrov, 2003):

1) saving of linguistic means, conciseness of presentation at informative saturation;

2) selection of linguistic means with the installation on their portability (TV is the most common form of mass media);

3) use of socio-political vocabulary and phraseology, rethinking the vocabulary of other styles (in particular, terminological vocabulary) for the purposes of journalism;

4) use of language stereotypes characteristic of this style, cliché;

5) genre diversity and its associated stylistic use of linguistic means: ambiguity of words, resources of word formation (author's neologisms), emotionally-expressive vocabulary;

6) features combination of a journalistic style with other styles (scientific, official-business, literary-artistic, and spoken), due to a variety of themes and genres;

7) use of figurative-expressive means of the language, in particular the means of stylistic syntax (rhetorical questions and exclamations, repetitions, inversions, etc.).

Not all of these features are equally true for all TV materials and mainstream media genres. The stylistic attachment of lexical and grammatical means is a relatively rare phenomenon and can be manifested in the modern language of television, the basis of which is the everyday vocabulary, which is a combination of elements of the vocabulary and syntactic structures of different styles. But it should be noted that at the same time, the stylistic colour is partially preserved or lost. The informative nature of the television style language is determined by the fact that it expresses integral information, pre-conceived and organized.

In the English-language material of 13 April 2014, "Fatalities reported as rival activists clash in Ukraine" (Euronews. Fatalities, 2014) is reported that according to local unnamed sources, "pro-Russian militant" was killed in Sloviansk in battles with pro-Ukrainian troops. Journalists do not think, but they claim, with reference to some unknown source, that there is a killed man and he is a gunman. Unlike other editions, English clearly states that it has been killed "in battles with Ukrainian troops". English journalists do not refer to amateur video, as their Ukrainian and Russian counterparts did, because they are not able to check / confirm the content. However, the only ones mention another amateur video that shows armed men who erect barricades at the exit from the city Sloviansk.

At the same time, only the English edition writes about Ukraine's accusations of the Kremlin: "Kyiv has blamed the Kremlin for the rash of rebellion against its ru1e. Moscow has warned that it will protect the region's Russian-speakers if they come under attack". It is not clear why journalists from other language services do not publish it.

The material in German entitled "Distinguishly known about one dead in Sloviansk battle" ("Mindestens ein Toter and Gefechten vor Slowiansk") (Euronews. Mindestens, 2014) also confirms the death of at least one person in battles near Sloviansk, at the very beginning of the "so-called Anti-Terrorist Operation" ("eines sogenannten Anti-Tepor-Einsatzes").

In the materials of 11 May 2014, one talks about how "separatists vote in a referendum" (Euronews. Separatysty, 2014). At the same time, the Ukrainian editorial unit focuses on the wording of the "so-called referendum / pseudo-referendum". And all who vote are called separatists. German journalists, meanwhile, use the term "majority of residents" who go to vote in order to vote for separation. That is, there are those who go to the polls, vote "against" and to call all people "separatists" is biased. Not all editors mention the initiator of the "referendum", only Ukrainian ("armed separatists") and German ("den prorussischen Separatisten", "separatists"). In the submission of information, the Ukrainian version is the most similar to English: "Se1f-rule" votes in Donetsk and Luhansk "step towards the abyss" says Kyiv as pol1s open") (Euronews. Self-rule, 2014). 
Journalists write: "There are no international or independent observers present to the oversee the ballot" or "millions of ballot papers have been printed", although in English is also added about the "pro-Russian activists" control of polls. About "armed men", who "loitered around the polls" in Luhansk is also reported in English.

On 11 May 2014, language editors report on the referendum. The Ukrainian service in the title ("Referendum on Donbas: "Potemkin villages" or "People's enthusiasm?") (Euronews. Referendum, 2014) informs about "window dressing" and allegedly "folk enthusiasm" in the referendum: "In Donetsk, employees of communal enterprises were "kicked" to the polls". Journalists from Luhansk and Luhansk regions report that there were several demonstration polls organized there, where all budget employees were taken to simulate mass voting. According to words of the head of the "poll" of the self-proclaimed "Donetsk People's Republic", in the morning more than $30 \%$ of attendance was recorded. For comparison, the Russian version, according to ITAR-TASS news agency, reports that the attendance in Donetsk "exceeded 50\%, in Luhansk - 75\%" (Thornton, 2015).

Returning to the information on the attendance, the German article refers to "more than $50 \%$ of the voters, and in Luhansk even as many as $80 \%$ ", who voted until the evening ("Demnach hatten in der Provinz Donezk bis zum Nachmittag mehr als fiinfzig Prozent der Wahlberechtigten Abbey, in the province of Luhansk sogar gut achtzig Prozent") (Euronews. Abstimmung, 2014). Not for the first time, German journalists analyze the audio information in their publications.

It is noteworthy that the English version does not provide information on the number of voters who have already voted. The non-recognition of the "referendum" by the Ukrainian government, the EU and the US ones is written about in four languages, and all four language versions cite the inhabitants of the city, who are convinced that Donbas can provide its economy itself, because it has factories and mines.

\section{CONCLUSIONS AND FURTHER RESEARCH PROSPECTS}

So, having analyzed the program content of the European media, Euronews, we state that the national editors of information programs actively covered events related to the controversy events in Ukraine, and the commencement of active hostilities in the East of Ukraine. At the same time, on its way to the air, the media product passes through a whole selection of fountains, interrogations, journalistic work, influences and saturation of media texts by lexical and stylistic forms inherited in one or another language. The audiovisual product, formed by multimedia channels, is received by the recipient. The same analysis of the produced content confirmed the constancy and saturation of the linguistic components of the information genre and showed, on the one hand, bias, prejudgment and manipulative nature of the mass communication activities of the Russian service Euronews, and, on the other hand, compliance with the standards of information television in Ukrainian, English and German editors.

Despite the fact that the channel declares the principled position of the editorial Euronews office, which is manifested in independence and neutrality in the supply of information, being free of any political or economic pressure, the editorial board does not evaluate and support any of the parties covered the conflicts, giving each of them the opportunity to express their own point of view.

We see our further research prospects in highlighting the problem of foreign language teachers' media literacy.

\section{References}

1. Ash, Timothy\&Gunn, Janet (2017). The Struggle for Ukraine. Chatham House Report. London, 126. [in English]

2. Baisnée, Olivier\& Marchetti, Dominique (2014). Producing "European" News. The Case of the Pan-European News Channel Euronews. HAL archives, 32. [in English].

3. Euronews. "Abstimmung in der Ostukraine über eine Unabhängigkeit". Accessed 17 September 2020. https://de.euronews.com/2014/05/11/abstimmung-in-der-ostukraine-ueber-eine-unabhaengigkeit. [in German].

4. Euronews. "EU verlängert Krim-Sanktionen". Accessed 17 September 2020. https://www.tagesschau.de/ausland/eusanktionen-russland-129.html. [in German].

5. Euronews. "Fatalities reported as rival activities clash in Ukraine". Accessed 16 September 2020. https://www.youtube.com/results?search_query=fatalities+reported+as+rival+activities+clash+in+ukraine. [in English].

6. Euronews. "Here we go: violence erupts in Ukraine as pro-Russia protesters ...". Accessed 17 September 2020. https://www.godlike.com/forum1/message2491887/pg1. [in English].

7. Euronews. "Khto kontrolyuye Donets'k pislya vidstavok ochil'nykiv MVS i SBU? [Who controls Donetsk after the resignations of heads of the Ministry of Internal Affairs and the SSU?]". Accessed 5 September 2020. https://www.youtube.com/watch?v=hRKaO_GB99o. [in Ukrainian].

8. Euronews. "Krym: rossiyskiy pasport po oblegchennoy protsedure? [Crimea: a Russian passport in a lightweight procedure?]". Accessed 5 September 2020. https://ru.euronews.com/2014/02/25/russia-extends-offer-of-citizenship-to-crimea. [in Ukrainian].

9. Euronews. "Live: Watch Euronews UK (English) from Un. Kingdom". Accessed 17 September 2020. https://wwitv.com/tv_channels/6645.htm. [in Russian].

10. Euronews. "Mindestens ein Toter bei Gefechten vor Slowiansk". Accessed 16 September 2020. https://de.euronews.com/2014/04/13/mindestens-ein-toter-bei-gefechten-vor-slowiansk. [in German].

11. Euronews. "NTKU i Euronews pidpysaly uhodu pro stvorennya ukrayinomovnoyi versiyi [NTCU and Euronews signed an agreement on the creation of the Ukrainian language version]". Accessed 5 September 2020. https://detector.media/withoutsection/article/56826/2010-10-21-ntku-i-euronews-pidpisali-ugodu-pro-stvorennyaukrainomovnoi-versii-euronews. [in Ukrainian].

12. Euronews. "Ostukrainische Regierungsgegner zwingen Polizeichef von Donezk zum Rücktritt". Accessed 5 September 2020. https://de.euronews.com/2014/04/12/ostukrainische-regierungsgegner-zwingen-polizeichef-von-donezk-zum-ruecktritt. [in German]. 
13. Euronews. "Pro-Russian separatists seize Donetsk police HQ". Accessed 5 September 2020. https://www.youtube.com/watch?v=z4ATK4SH5qc. [in English].

14. Euronews. "Referendum na Donbasi: "potiomkinski sela" chy narodnyy entuziazm? [Referendum on Donbas: "Potemkin villages" or folk enthusiasm?]". Accessed September 2020. https://www.youtube.com/watch?v=GQMANgOVTGI. [in Ukrainian].

15. Euronews. "Self-rule" votes in Donetsk and Luhansk. A "step toward the abyss" says Kyiv as polls open". Accessed 16 September 2020. https://www.euronews.com/2014/05/11/self-rule-votes-in-donetsk-and-luhansk-a-step-toward-theabyss-says-kyiv-as. [in English].

16. Euronews. "Separatysty holosuyut na "referendumi" [Separators vote on the "referendum"]". Accessed 16 September 2020. https://www.youtube.com/watch?v=S7Q9WJaZ1VY. [in Ukrainian].

17. Euronews. "2014 Ordinary Session (Second part). Report. Sixteenth sitting, Thursday 10 April 2014". Accessed 17 September 2020. http://assembly.coe.int/Documents/Records/2014/E/1404101000E.htm. [in English].

18. Herman, Edward\&Chomsky, Noam (1988). Manufacturing Consent: The Political Economy of the Mass Media. New York, 412. [in English].

19. Myers, Steven\&Smale, Alison. Russian Troops Mass at Border With Ukraine. Accessed 17 September 2020. https://www.nytimes.com/2014/03/14/world/europe/ukraine.html. [in English].

20. Previsic, Boris (2014). Erzählte Mobilität im östlichen Europa. (Post-) Imperiale Räume zwischen Erfahrung und Imagination. Accessed 17 September 2020.

https://www.academia.edu/35209810/Erz\%C3\%A4hlte_Mobilit\%C3\%A4t_im_\%C3\%B6stlichen_Europa._Post_Imperiale_R\%C3\%A4ume_zwischen_Erfahrung_und_Imagination. [in English].

21. Steinmeier, Frank (2014). A Fresh Look at German Foreign Policy. Accessed 17 September 2020. https://www.auswaertigesamt.de/en/newsroom/news/140520-bm-review2014-abschlussrede/262346. [in English].

22. Thornton, Rod (2015). The Changing Nature of Modern Warfare. Responding to Russian Information Warfare. The RUSI Journal, 160:4. Accessed 5 September 2020. https://www.tandfonline.com/doi/full/10.1080/03071847.2015.1079047. [in English].

23. Vladymyrov, Volodymyr (2003). Zhurnalistyka, osoba, suspil'stvo: problema rozuminnya: monohrafiya [Journalism, person, society: the problem of understanding: monograph]. Kyiv: Taras Shevchenko KNU, 220. [in Ukrainian].

\section{ОСОБЛИВОСТІ ВИСВІТЛЕННЯ ТА ІНТЕРПРЕТАЦІЇ КОНТРАВЕРСІЙНИХ ПОДІЙ В УКРАЇНІ ЄВРОПЕЙСЬКИМИ ЗМІ Олена Биндас}

Анотація.

Дз «Луганський національний університет імені Тараса Шевченка», Україна

Постановка проблеми. у статті розглядається проблема багатовимірного розкриття особливостей висвітлення та інтерпретації інформації про контроверсійні події в Україні під час інформаційної війни в ефірі європейського телеканалу міжнародних новин - Euronews.

Результати. Автор наголошує, що, незважаючи на існування єдиної редакційної політики, журналісти редакції Еитопешs самостійно пишуть текст до вибраних новин, тому його абсолютна ідентичність майже неможлива. Фактично, аналіз виробленого контенту підтвердив сталість і насиченість лінгвістичних компонентів інформаційного жанру та показав, з одного боку, упередженість та маніпулятивний характер діяльності засобів масової комунікації російської служби Еигопешs, а також з іншого боку, дотримання стандартів медіаграмотності в українських, англійських та німецьких редакціях. У той час, коли інформаційна війна супроводжується військовими діями Росії проти України, проблема дотримання правил медіаграмотності в публікаціях ЗМІ є особливо актуальною. Важливо поширювати правдиву інформацію про події в Україні як у нашій країні, так і за їі межами. Таким чином, це дослідження є актуальним, і вибір об'єкта та джерельної бази дослідження цілком логічний: телеканал "Еuronews" транслює на тринадцяти мовах і охоплює широку аудиторію в різних країнах.

Висновки. Проаналізувавши програмний зміст європейських ЗМІ, ми констатуємо, що національні редакції інформаційних програм активно висвітлювали новини, пов'язані з контроверсійними подіями в Україні. В той же час, виходячи в ефір, медіапродукт проходить через цілу низку важливої інформації, обговорень, журналістської роботи, навіювань та насичення медіатекстів лексико-стилістичними формами, успадкованими тією чи іншою мовою. Але редакційна колегія не оцінює і не підтримує жодну зі сторін, що висвітлюють конфлікти, надаючи можливість кожній із них висловити власну точку зору.

Ключові слова: редактор, канал, транслячія новин, територіальний конфлікт, Схід України, європейські зМІ. 